\title{
Volga Bulgarian-Permic linguistic contact: Mutual influences on morphology
}

\author{
Julian Kreidl*
}

\begin{abstract}
In this paper, I argue that three morphological (morphosyntactic) features in Udmurt, Komi, Volga Bulgarian and Chuvash show mutual influence between the ProtoPermic and Volga Bulgarian languages in the Volga-Kama area in the late first millennium CE: First, the formal identity of the Permic accusative and 3sg possessive suffixes which does not have parallels in Uralic but in Turkic. Second, the Volga Bulgarian and Chuvash plural marker -sem, which is unknown from other Turkic languages. Third, the prohibitive particle an in Chuvash, which does not have cognates in Turkic and is loaned from ProtoPermic.
\end{abstract}

Keywords. Volga Bulgarian, Chuvash, Proto-Permic, Udmurt, Komi, morphology, language contact

1. Sources and Transcription. Sources are given in brackets; examples which appear without references are from my own research and fieldwork. For languages which do not use the Latin alphabet I have used the established transcription methods in the respective fields. The transliteration system common in Uralic linguistics (Uralic Phonetic Alphabet) differs in some respects from IPA; note $\hat{\partial}=[ə], \mathrm{i}=[\mathrm{i}], \mathrm{dź}=[\widehat{\mathrm{d} \not ̧]}], \mathrm{s}=[6], \dot{z}=[\mathrm{b}], \check{\mathrm{z}}=[3]$.

2. Introduction. In the late $1^{\text {st }}$ millennium $C E$, speakers of Volga Bulgarian and Permic were in close contact, with Rédei, Róna-Tas 1982 and 1983 showing that lexical borrowing happened in both directions. Whether borrowings or calques also took place on a morphological and syntactic level, and if so, to which degree it happened, is still unclear. In the course of the following pages, I want to draw attention to three features which are common to Permic and Oghur (Volga Bulgarian and Chuvash) but are atypical for either Uralic or Turkic more broadly, and could therefore be due to Volga Bulgarian-Permic linguistic contact. These three features are the Permic accusative suffix, the Volga Bulgarian, Chuvash and Permic plural morphemes, and the Chuvash prohibitive marker.

3. The Permic accusative suffix. Like Turkic languages, Komi and Udmurt show differential object marking: Direct definite objects require the accusative (-jez), while direct indefinite objects have a zero ending (= accusative with zero morpheme). Compare the following two sentences in Udmurt:

(1) Udmurt (Christian Pischlöger, personal communication)

mon kńiga lidź-iśko

I-NOM book-[ACC] read-1SG.PRES

\footnotetext{
${ }^{*}$ I want to thank Christian Pischlöger from the project LIDIVOKA (Linguistic Diversity in the Volga-Kama Region) and Jeremy Bradley from the Department of Finno-Ugric Studies, University of Vienna, for looking over my Udmurt, Komi and Mari examples. I would also like to thank the anonymous reviewers for additional suggestions and drawing my attention to errors. All remaining mistakes are my own, of course. Author: Julian Kreidl, Indiana University Bloomington (jkreidl@iu.edu).
} 
'I'm reading a book.'

(2) Udmurt (Christian Pischlöger, personal communication)

mon kńiga-jez liddź-iśko

I-NOM book-ACC read-1SG.PRES

'I'm reading the book.'

The Udmurt accusative suffix (and Komi - ös) cannot be related with the Uralic accusative *-m which was lost in Proto-Permic due to regular sound change (Csúcs 2005: 175). ${ }^{1}$ This secondary Permic accusative suffix is conspicuously close to the $3 \mathrm{sg}$ possessive suffix, Proto-Permic *-is *-iz (Csúcs 2005: 199-200). Going back to our Udmurt example above, it means that the accusative in -jez is formally identical with the nominative with the 3 sg possessive suffix. Wichmann 1923: 160 suggested that the new ending to mark the definite direct object may originally be identical with the $3 \mathrm{sg}$ possessive suffix, and this theory has become communis opinio in Uralic linguistics.

The similarity of the two endings is strongly reminiscent of the Turkic languages, where the 3 sg possessive suffix often looks similar to the accusative marker, although total formal identity is generally prevented, e.g. Turkish accusative $-(y) I, 3 \mathrm{sg}$ possessive $-(s) I$ and Uzbek accusative $-(n) i, 3$ sg possessive $-(s) i$. I argue that these two morphmes were formally identical to an even greater extent in the Turkic language the Proto-Permians were in contact with; it may have been a specific Oghur Turkic feature, as not every Turkic language shows the same formal identity.

In Old Turkic, the accusative ending was $-I g$, which is replaced by the pronominal accusative marker $-n I$, especially if the noun ends in a vowel, in the course of later Old Turkic. It is especially common in the latest Old Uyghur documents and inscriptions (Erdal 2004: 170). The tendency has continued in e.g. the Kipchak and Karluk branches (see e.g. Tatar - $n(I)$, Uzbek -ni). Chuvash is known for the merger of the dative and accusative, and the same idiosyncrasy is already visible in the Volga Bulgarian tombstone inscriptions. In both languages, the dative took over the functions of the accusative, which was given up. But before this happened, Oghur Turkic must have had an accusative too. In light of the Old Turkic data, its ending was most likely $*-I \gamma$.

In Old Turkic, the 3 sg possessive suffix is $-(s) I$ in the nominative, $-(s) \operatorname{In}$ in the oblique cases, with the sibilant acting as a hiatus breaker after a final vowel, as in many contemporary Turkic languages (Erdal 2004: 160-162). This means that neither in Old Turkic nor, presumably, in Proto-Turkic there was any danger of confusing the acc.sg and 3 sg possessive suffixes ${ }^{2}$; the partial formal identity only arises with the replacement of the old acc.sg -Ig in Old Turkic. In Volga Bulgarian, the $3 \mathrm{sg}$ possessive suffix is only attested as $-i$ or possibly synharmonic $-I$, even

\footnotetext{
${ }^{1}$ The original Uralic accusative is, at least indirectly, attested in a second accusative suffix preserved, e.g. in pronouns menö 'me', tenö 'thee'. The final vowel represents the vowel before the accusative *- $m$ which was dropped.

${ }^{2}$ Even more so, in Proto-Turkic, the later 3sg possessive morpheme may still have been an independent pronoun, $\mathrm{cf}$ Erdal 2004: 162.
} 
after vowels. ${ }^{3}$ The Volga Bulgarian orthography would also allow the interpretation as back vowel $-\ddot{l}$ in the appropriate environments, but in light of the Chuvash data it is unclear the $3 \mathrm{sg}$ possessive suffix was actually subject to vowel harmony. In Chuvash, the vowel of the $3 \mathrm{sg}$ possessive suffix is invariably a front vowel $-\breve{e}$ (cf the cognates Chuvash $\ddot{v} v a ̆ l-\breve{e}$, but Bashkir $u l-\ddot{l}$ 'his/her son'). Note that the existence of a disharmonic, front vowel, $-(s) i(n)$ cannot be excluded for at least some, chronologically earlier, layers of Old Turkic, although this hinges on the interpretation of the Orkhon Turkic orthography (Erdal 2004: 163). ${ }^{4}$ In theory, it cannot be ruled out that the state of affairs in Chuvash, where the 3sg possessive is always front vowel $-\breve{e}$, is an innovation. But we should keep in mind that vowel harmony is generally productive in Chuvash, and its loss in this suffix would in any case not be a too recent phenomenon.

Therefore, we can suppose that Oghur Turkic in the first half of the $1^{\text {st }}$ millennium CE had an accusative suffix $*_{-} I g>*_{-} I \gamma$, and a productive 3 sg possessive suffix $*_{-} i$. Towards the end of the $1^{\text {st }}$ millennium $\mathrm{CE}$, due to the loss of the guttural, the acc.sg ended in $*_{-} I$, which made it phonetically close to the $3 \mathrm{sg}$ possessive suffix $*_{-} i$; $*_{-} i$ was unproductive and only preserved in some kinship terms. At this point, the calque from Oghur Turkic into Proto-Permic may have happened. The bilingualism of many Permians led to the introduction of this (near) formal identity of the acc.sg and the 3sg.poss.suff also in their language. ${ }^{5}$ Because the old Uralic acc.sg $*_{-} m$ had been lost, a new one was created by means of the Proto-Permic $3 \mathrm{sg}$.poss.suff $*_{-i s} \sim *_{-i z}$, a morpheme which was inherited from Proto-Uralic. ${ }^{6}$ Until today, the $3 \mathrm{sg}$ possessive, instead of the accusative, can be employed to mark a direct object as definite in both Komi and Udmurt. ${ }^{7}$

Such calques on a morphological and/or syntactical level can also be observed in other regions of intense linguistic contact involving Turkic languages. I shall give an example from Tajik dialects spoken in Uzbekistan and Tajikistan. In line with the use of the object marker $-r \bar{a}$ in other Persian varieties, the Tajik $-a(<$ shortened $-r \bar{a})$ functions as an accusative equaling Uzbek -ni. For example:

(3) Colloquial Tajik (author's fieldwork)

Odam-a me-bin-am

man-ACC PRES-see-1SG

'I see the man.'

(4) Standard Uzbek

Odam-ni ko'r-yap-man

\footnotetext{
${ }^{3}$ A variant $-s i$ (or $-s I$ ) is not attested in the rather small Volga Bulgarian corpus (cf also Erdal 1993: 91). Its use in

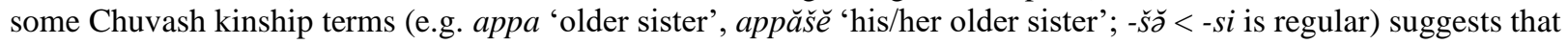
it may have been marginally employed in Volga Bulgarian too, but certainly not as a productive suffix.

${ }^{4}$ Whether this potentially shared feature between Chuvash and Old Turkic means that the 3 sg possessive marker was also disharmonic in Proto-Turkic cannot be addressed here, but would be an obvious conclusion.

${ }^{5}$ Note that Wichmann 1923: 160 explains the Permic idiosyncracy from within Permic and does not think of Turkic influence.

${ }^{6}$ For an overview of the development of the 3sg possessive suffix from Uralic to Permic cf Csúcs 2005: 197-200.

${ }^{7}$ Cf Csúcs 2005: 195. A determinative use of the 3sg possessive suffix, which is reminiscent of, although not exactly the same as in Permic, can also be observed in Chuvash and other Turkic languages, cf Benzing 1993: 6-7.
} 
man-ACC see-PRES-1SG

'I see the man.'

This is not surprising and hardly unusual. But because the Uzbek genitive suffix -ning is commonly realized as $-n i$ in many dialects, the accusative and genitive have become formally identical in most colloquial registers of Uzbek. As Tajik speakers equal the Uzbek - $n i$ with Tajik $-a$, it has become common that Tajik - $a$ also serves to form genitive constructions - something which is unknown from Persian varieties in Afghanistan and Iran and can only be explained by the contact situation. The Uzbek influence on Tajik has been so intense that local Tajik dialects even prefer a Turkic style genitive construction to the traditional izafet (or ezafe, glossed EZF) compound. Compare the following examples:

a. Standard Tajik

kitob-i pidar

book-EZF father

'father's book'

b. Standard Uzbek

ota-ning kitob-i

father-GEN book-3SG-POSS

'father's book'

(6) a. Colloquial Tajik (author's fieldwork)

padar-a kitob-aš

father-ACC(/GEN) book-3SG.POSS

'father's book'

b. Colloquial Uzbek (author's fieldwork)

ota-ni kitob-i

father-ACC/GEN book-3SG.POSS

'father's book'

In light of this example, I think it is not too audacious to claim that a similar morphological calque happened in the Volga Bulgarian - Permic contact situation.

Coming back to Volga Bulgarian specifically, it seems that the very (near-)formal identity which had been calqued into Permic was increasingly seen as an issue by Volga Bulgarian native speakers. By the time of the Volga Bulgarian epitaphs, they had given up the accusative, and the dative $-A$ had taken over the functions of the former accusative. It is not entirely clear why this happened, but several competing theories seem possible at least at first glance: 
1. The merger was simply due to (inner-Volga Bulgarian/Chuvash) phonological reasons: Namely the phonological merger of the dative and accusative morphemes.

2. The two cases eventually merged because of (inner-Volga Bulgarian/Chuvash) morphosyntactic reasons: Due to the at least partial formal identity of the accusative and $3 \mathrm{sg}$ possessive suffixes, the accusative was given up to mark a definite object.

3. The accusative was abandoned because of external (most likely Uralic) influence.

Regarding the first possibility, it needs to be emphasized that Turkic *A (as in the dative $*_{-} G A$ or $*_{-} K A$ ) and $*_{I}$ (accusative $*_{-} I g$ ) do not, at least not regularly and not in final syllables, merge in Oghur Turkic. The merger could have happened if we assume that the starting point for the accusative was a suffix *-Ag; this does indeed exist for Old Turkic, but only as a variant. Therefore, we would need to suppose that $*_{-} A g$ was generalized (to the detriment of $*_{-} I g$ ) in an earlier form of Volga Bulgarian and Chuvash, and the dative $*_{-} G A$ and accusative $*_{-} A g$ coincided after the deletion of the guttural. This is suggested by Róna-Tas 1976: 171. The issue here is we have no evidence in either Oghur or non-Oghur Turkic about the generalization of the accusative suffix $*_{-} V g$ as $*_{-} A g$. Therefore, many scholars have abandoned this theory, e.g. Erdal 1993: 97, who thinks that a "funktionelle Neutralisierung der Aufgaben der beiden Kasus" is to be preferred, which would speak for option number 2, or theoretically also number 3 .

The second theory takes as starting points Turkic $*_{-} G A$ for the dative and $*_{-} I g$ for the accusative. After the loss of the guttural, this would leave $*_{-} A$ for the dative and $*_{-} I$ for the accusative in Oghur Turkic. Here, we could assume that the homonymity of the accusative $*_{-} I$ and the $3 \mathrm{sg}$ possessive suffix $*_{-} I$ created a problem, and the former was given up already before the earliest known Volga Bulgarian inscriptions. The task of marking the definite direct object was taken over by the case which was used to mark the indirect object: the dative. Levitskaja 1976: 19, who talks about the dative-accusative merger in Chuvash only, suggests that the accusative was abandoned in Chuvash after the change Turkic $*_{-} i>$ Chuvash $-\check{e}$ not only because of the abovementioned reason, but also because of the small phonemic value of $\breve{e}$ [ə], which was not considered fit to mark definite direct object. Because the accusative had already been abandoned by the time of the Volga Bulgarian epitaphs (where Turkic $*_{i}$ is still by and large unreduced $i$ ), it is clear that the possible small phonemic value did not play crucial role. But even before the Chuvash vowel change, the problem of the homonymity of the accusative and 3sg possessive *-I remained. Therefore, one was given up for the sake of clarity. It also suggests that there was little to none intense contact between speakers of Volga Bulgarian and other Turks in the second half of the 1st millennium, from whom the Volga Bulgarians could have learned the "mainstream" Turkic strategy of differentation between the accusative and 3sg possessive morphemes by minor phonological adjustments. ${ }^{8}$

The third option argues for outside influence. Currently, none of the languages in the geographical neighborhood of Chuvash shows a dative-accusative merger. The only language which at some point did not have a proper accusative was arguably Proto-Permic before it created a new accusative: Because both the Uralic lative $*_{-} \eta$ and the accusative $*_{-} m$ had been lost

\footnotetext{
${ }^{8}$ If this theory is correct, it is also interesting to note that the alternative $3 \mathrm{sg}$ possessive suffix $-s i$ was apparently not seen as a feasible avoidance strategy anymore. This means that already in Volga Bulgarian, -si was a fossilized and unproductive morpheme at best.
} 
word-finally, both cases were at that time marked by a formally identical vocalic ending. ${ }^{9}$ Because the functions of the Uralic lative overlap with the Turkic dative, we find a situation which is reminiscent of the Volga Bulgarian dative-accusative merger. Needless to say, we cannot assume that the dative-accusative merger in Volga Bulgarian is due to Permic influence while at the same time claiming that the new Permic accusative was modeled after the old Volga Bulgarian accusative. This is logically impossible. Assuming Proto-Permic influence as the reason for the loss of the accusative in Volga Bulgarian would mean that the latter merged dative and accusative considerably earlier than 1308, when the merger is attested in a Volga Bulgarian epitaph. It would push the date of when Volga Bulgarian lost the accusative well into the $1^{\text {st }}$ millennium CE, before Proto-Permic, which dissolved by the $10^{\text {th }}$ century at the latest, introduced the secondary accusative. This cannot be ruled out per se, but involves more uncertainty than assuming that the Proto-Permic accusative is a Volga Bulgarian calque.

Therefore, for the time being, the most probable cause for the loss of the Proto-Turkic accusative in Volga Bulgarian is its problematic formal identity with the 3sg possessive marker, which had caused the subject (when containing the 3sg.poss.suff) and the direct definite object to be either formally identical. ${ }^{10}$ If this theory is correct, however, it is interesting that the same formal identity which later constituted a problem in Volga Bulgarian was calqued by the ProtoPermians when they created a new accusative.

The process described above can be divided into three stages:

\begin{tabular}{|l|l|l|}
\hline Stage & Proto-Permic & Volga Bulgarian \\
\hline I & $\begin{array}{l}\text { Uralic acc.sg } *_{-} m \text { had been } \\
\text { lost }\end{array}$ & $\begin{array}{l}\text { accusative formally identical with } \\
\text { 3sg possessive suffix }\end{array}$ \\
\hline II & $\begin{array}{l}\text { accusative }=3 \text { sg possessive } \\
\text { calqued from Volga } \\
\text { Bulgarian }\end{array}$ & $\begin{array}{l}\text { accusative formally identical with } \\
\text { 3sg possessive suffix }\end{array}$ \\
\hline III & accusative $=3$ sg possessive & $\begin{array}{l}\text { accusative is given up; direct } \\
\text { definite object expressed by dative }\end{array}$ \\
\hline
\end{tabular}

Table 1: The development of the secondary accusative in Proto-Permic

4. The Volga Bulgarian and Chuvash plural marker. One of the many idiosyncracies of Volga Bulgarian and Chuvash is the lack of the Common Turkic plural marker -lAr, and the use of -sem instead. In the corpus of Volga Bulgarian, the plural is attested twice, in one inscription:

Volga Bulgarian (Erdal 1993: 32)

'ulamā-sem-ne sew-en, mesǰid-sem-ne 'emāret tạ-an ekil xayrāt-lu ... Alïp Xowājăah ulama-PL-3SG.POSS-D/A loving-PRESP, mosques-PL-3SG.POSS-D/A building doingPRESP many wonder-with ... Alïp Xowāǰah

'the ulama-loving, the mosques-building, with many wonders ... Alïp Xowājah (Alp Xwāja)'

\footnotetext{
${ }^{9}$ Cf. Wichmann 1923: 160. Note that Wichmann supposes *- $k$ for the Proto-Uralic lative case, in line with many other earlier Uralicists. However, Aikio forthcoming: 25 convincingly reconstructs $*_{-} \eta$ (see also p. 20).

${ }^{10}$ Or nearly identical, if we argue that Volga Bulgarian did indeed have a back-vowel variant of the $3 \mathrm{sg}$ possessive morpheme.
} 
In the inscription, -semne is written with vocalization as wَسَن which would theoretically also allow an interpretation with back vowel suffixes, but the available data from Chuvash and Mari renders it unlikely, as we shall see. ${ }^{11}$

Like the dative-accusative merger, the choice of the plural suffix is a strong link between Volga Bulgarian and Chuvash. However, not only the morpheme itself, but also how it is combined with possessive pronouns sets Chuvash apart from other contemporary Turkic varieties. The following table lists the translation of 'my books' in four different Turkic languages, and we can see that all Common Turkic dialects - including Tuvan and Turkish, which lie on opposite ends of the Turkic linguistic area - place the plural suffix before the possessive suffixes.

\begin{tabular}{|l|l|l|l|l|}
\hline Chuvash & Tatar & Turkish & Uzbek & Tuvan \\
\hline kĕneke-m-sem & kitap-lar-lm & kitap-lar-lm & kitob-lar-im & nom-nar-ïm \\
\hline book- & book-PL- & book-PL- & book-PL- & book-PL- \\
1SG.POSS-PL & 1SG.POSS & 1SG.POSS & 1SG.POSS & 1SG.POSS \\
\hline \multicolumn{4}{|c|}{ 'my books' } \\
\hline
\end{tabular}

Table 2: The plural and possessive suffix in Turkic languages

Note that Tatar, too, aligns with the other Turkic languages, and not with Chuvash. Although Tatar and Chuvash share some areal features, and Tatar had exerted lexical and other influence on Chuvash in the last 500 years, there is clearly no similarity as regards the plural formation among Volga Turkic languages. ${ }^{12}$

The situation in the Uralic languages is likewise interesting. Generally, Uralic follows the cross-linguistically more widespread, and also Common Turkic, order of plural+possessive suffix. This has also been reconstructed for Proto-Uralic (Aikio forthcoming: 29). However, it must be pointed out that Mari, which is spoken to the northeast of Chuvash, allows both orders:

\begin{tabular}{|l|l|l|l|}
\hline \multicolumn{2}{|c|}{ Meadow Mari (Krasnova et al. 2017: 75) } & \multicolumn{2}{c|}{ Hill Mari (Krasnova et al. 2017: 75) } \\
\hline pört-e-m-vlak & pört-vlak-em & pört-em-vlä & pört-vlä-em \\
\hline $\begin{array}{l}\text { house-1SG.POSS- } \\
\text { PL }\end{array}$ & house-PL-1SG.POSS & house-1SG.POSS-PL & house-PL-1SG.POSS \\
\hline \multicolumn{2}{|r}{ 'my houses' } \\
\hline
\end{tabular}

Table 3: The plural and possessive suffixes in Mari

Apart from - vlak which is most common in literary Meadow Mari, Eastern Mari varieties have several other suffixes which are missing from Hill Mari: -môt, -la and -šamâč (Krasnova et al. 2017: 67). The latter has often been connected with the Volga Bulgarian and Chuvash -sem,

\footnotetext{
${ }^{11}$ Note that the Volga Bulgarian orthography uses sin regardless of the quality of the vowel; the differentiation sin (for front vowel environment) - șad (for back vowel environment) known from other Turko-Arabic orthographies is not used on the tombstones (Erdal 1993: 87).

${ }^{12}$ For Tatar loanwords (of Perso-Arabic origin) which were borrowed into Chuvash (Scherner 1977). The ultimate source of the "Volga Vowel shift" in Chuvash, Tatar, Bashkir and Mari is still debated.
} 
where $-y \check{c}$ would represent an additional inflectional suffix added in Mari. ${ }^{13}$ While the connection between -šamôč and -sem has been widely acknowledged (first proposed by Budenz 1864: 434), the direction of the borrowing was long unclear. As with many features shared by Chuvash and Mari, Turkologists had traditionally often supposed Uralic influence, while Uralicists assumed Turkic influence, just because the features in question bind Chuvash and Mari together, but are often odd from both a Turkic and Uralic perspective. But most scholars who have worked on the issue of the pluralization in Chuvash and/or Mari from a diachronic perspective in the last decades agree that the suffix is originally Chuvash, although the exact etymology remains debated (see below).

The Meadow Mari plural -šamâč seems to point to a front vowel morpheme too. Although both Proto-Mari $* a$ and $* \ddot{a}$ show up as $a$ in Meadow Mari in initial syllables (while $* e$ $>e$ ), the palatalization of $*_{s}$ to $\check{s}$ suggests a front vowel environment: $*_{s a ̈ m-.}{ }^{14}$ However, the lack of data from other Mari dialects prevents a more secure internal reconstruction. But in light of the contemporary Chuvash usage, which also points to an original front vowel morpheme, it seems the Mari plural suffix is one more piece of evidence that the original, including Volga Bulgarian, vocalization of this morpheme was *sem (or *säm or the like). ${ }^{15}$ If the, in my opinion less probable, hypothesis in Adamović 1983 (see below) would turn out to be right, it would also point to a front-vowel etymon.

Another peculiar feature of the Volga Bulgarian plural suffix is the fact that the attested form (a dative-accusative) clearly contains an alveolar nasal: -semne, and not $†$-seme. Very possibly, this is a pronominal $n$. Erdal 1993: 88 takes up the ideas of Benzing 1959: 721-722 and Doerfer 1996: 37 that the Volga Bulgarian (and Chuvash) plural suffix may have originally been a noun, which could explain the odd features of the plural, including both the dative-accusative $n e$ (instead of $-e$ ) and the missing vowel harmony: If we assume that $*_{s e m}$ - regardless of its origin and exact phonetic shape - meant something like 'sum, number, entirety', the starting point would be a compound genitive, e.g., *mesjid semi 'the entirety of mosque(s)'. This, in turn, could explain the VB dative-accusative plural mesjidsemne, as it would come from an earlier *mesjid semi-n-e. In the course of time, the 3sg possessive $-i$ was elided, yielding mesjid-sem-ne, and the ending was further simplified to -sene in modern Chuvash. Because the morpheme was originally an independent noun and not a suffix, its vowel did not (and does not in Standard Chuvash) harmonize with the preceding element.

While the plural suffix is not attested with possessive suffixes in Volga Bulgarian, there is no reason to assume it would not have been the same "odd" (from a common Turkic standpoint) order as in Chuvash. The Chuvash, and rather un-Turkic, order "possessive suffix+plural suffix" is likewise easily explained with the proposed theory: Chuvash kĕnekemsem 'my books' may thus go back to *kinige-m sem-i 'the amount of my book(s)'. ${ }^{16}$

If this theory holds, it would mean that *sem was originally a nominal (with the meaning 'amount, number' or similar). The most likely origin is Benzing's proposal of connecting the

\footnotetext{
${ }^{13}$ Luutonen 1999: 91 agrees with others that this -âč may be the 2nd person possessive suffix, which can indeed not be ruled out.

${ }^{14}$ For reflexes of Proto-Mari initial syllable vowels in the Mari dialects see Aikio 2014: 143.

15 The dialectal Chuvash $-s A m$ is secondary.

${ }^{16}$ Instead of †kinige semim 'my amount of books' (Chuvash †kĕnekesemĕm), which has the common order "plural suffix+possessive suffix" known from other Turkic (and Uralic) languages.
} 
plural suffix with Chuvash sum 'score, (large) amount of money, wealth; ruble' and thus also the Oghur Turkic loanword in Hungarian szám 'number', both supposedly from *sām, the Old Oghur counterpart of Old Turkic sān 'number' (Benzing 1959: 722). For semantic and phonological reasons, this derivation is in my opinion more attractive than the idea of connecting it with Common Turkic sayïn 'everyone' (Ramstedt 1952: 58-59) or the assumption that -sem contains two Turkic plural suffixes *-sa and *-In (Pritsak 1957: 150). But also Benzing's hypothesis faces problems which need to be explained: *sām clearly does not contain a front vowel, which is strongly favored by contemporary Chuvash -sem and possibly also by Mari $\check{s} a m \hat{c} c ̌$. Although Viryal/Upper Chuvash varieties have a plural suffix $-s A m$ which follows vowel harmony, it is unlikely that the form without vowel harmony represents an innovation, given that vowel harmony is productive in Chuvash. ${ }^{17}$ Benzing 1959: 722 thinks that -sem is due to umlaut and goes back to *sāmi via *samĕ, while the Viryal -sAm may come from *sām without the possessive suffix. But if that were true, we would need to explain why $*_{s} \bar{a} m$ did not take the $3 \mathrm{sg}$ possessive suffix in some Chuvash dialects. Taking the Volga Bulgarian specimen from above, we would need to suppose a construction *mesjid sam 'mosques' (lit. 'mosque number', instead of mesjid semi) in some "Old Chuvash" or Volga Bulgarian dialects, which is unexpected and unattested, but not impossible. ${ }^{18}$

However, far more problematic is that modern Chuvash data itself doesn't speak in favor of that theory. If dialectal $-s A m$ were really due to the fact that some dialects did not use the $3 \mathrm{sg}$ possessive $-i$ in the plural construction, we would expect forms like dative-accusative $\dagger c ̌ a ̆ v a s ̌ s a m a$ instead čăvašsana '(to) the Chuvashs' in Viryal/Upper Chuvash. If there were no 3 sg possessive marker, the pronominal $n$ would lose its purpose, and we would have $\dagger-s \bar{a} m-a>$

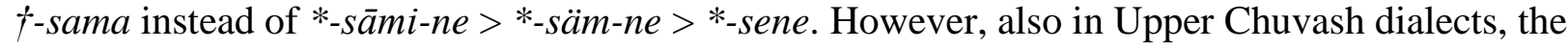
dative-accusative plural is always $-s A n A$, never $\uparrow-s A m A$.

It is thus more likely that the original form was "noun+sam+i" which was then umlauted to "noun+sem", and only later acquired a synharmonic form -sam in the northern dialect. The discrepancy that Old Oghur *sām yields sum 'score etc' on the one hand and -sem $\left(<*_{s a m-i)}\right.$ on the other is easily explained: Old $* a$ regularly gives $u$ in initial syllables in modern Chuvash, while it remains $a$ in non-initial syllables. For example: ulma 'apple' <*alma, ura 'leg, foot' < *(h)adak, xula 'city' < *qala, xura 'black' < *kara.

The concern that a word with the meaning 'number' (or 'sum', 'entirety', and the like) is unlikely to develop into a plural marker is unfounded. While there are no examples from other Turkic languages, cross-linguistic examples where a word meaning 'all', 'people' and the like develops into a plural morpheme are plenty. ${ }^{19}$ There are also parallels in Uralic. The Permic languages are known to have given up the original Uralic plural suffix $* t$ in favor of a secondary element which likewise started out as an independent noun and was later grammaticalized: The nominal plural endings in Udmurt and Komi are $-(j) o s$ and -jas, respectively, which are to be

\footnotetext{
${ }^{17}$ Note that also the 3 sg possessive suffix $-\breve{e}\left(<*_{-} i\right)$ has preserved the Proto-Turkic stage and resisted vowel harmonization. In this respect, Chuvash is quite conservative, and while there is no indication for -sem being inherited from Proto-Turkic, it makes it at least less likely that -sem should be an innovation as opposed to -sAm.

${ }^{18}$ There are parallels in Common Turkic languages, if we are allowed to compare forms like Altai (Oyrot) altay til 'Altai language, Altaian language' (but, e.g., Turkish Altay dili uses the possessive marker) or the Uzbek alternation bolalar yozuvchi and bolalar yozuvchisi 'children's (book) writer'.

${ }^{19}$ See for instance Luutonen 1999 on the parallels in Chuvash, Mari, Permic and Indo-Aryan languages.
} 
connected with Udmurt jos 'joint; member' and Komi jezz 'people'. ${ }^{20}$ Because all Permic varieties show this innovated plural morpheme (including Old Permic -jas, rarely -jös, Lytkin 1952: 106), the replacement of the original Uralic plural marker must have occurred around the turn of the first to the second millennium $\mathrm{CE}$ at the latest, after which the Proto-Permic community split up. At this time, the Proto-Permians and Volga Bulgarians had intense contact, which is also shown by a large number of Oghur loanwords in Permic and later in individual Permic languages. Of course, due to the different phonetic shape of the Permic and Oghur plural suffixes a borrowing from one into the other language must be excluded, but a shared areal innovation is feasible. It is unclear which language underwent an innovation in its pluralization first, because both Permic and Volga Bulgarian only give us a terminus ante quem (up to 1000 CE, more likely a century earlier, for the dissolution of Proto-Permic and 1308 for the one attested VB plural) ${ }^{21}$. Given the early split between Oghur and Common Turkic, it is hard to come up with a terminus post quem for Volga Bulgarian and Chuvash. In light of the missing vowel harmony and the fact that the nominal origin of Volga Bulgarian -sem was still visible (pronominal $n$ ), one could convincingly argue that it cannot be a very old (e.g. early 1 st millennium CE or even before) innovation. ${ }^{22}$ The situation on the Permic side is not really more illuminating, as we only know that at some point in the evolution from Proto-Uralic to ProtoPermic the change must have happened. Because there is no reconstructable stage between Proto-Uralic and Proto-Permic, which would bind the Permic languages closer to other subgroups of Uralic and provide us with a more precise dating, it is hard to tell when the innovated plural marker came into being. However, given that according to Luutonen 1999: 80 the plural marker was still sometimes written separately from the base in the Old Permic inscriptions of the 14th century (Lytkin 1952: 106 does not mention this), we can suppose that the change happened much closer towards late Proto-Permic, in the second half of the first millennium CE. Luutonen 1999: 80, 84 suggests that the innovation took place not long before the arrival of the Bulgars in the Volga region, and was therefore not triggered by Turkic influence. The fact that the loss of Proto-Uralic *-t can be explained by Permic phonological processes ( $* t$ yields $\varnothing$ in Proto-Permic) and that the new plural formation is built on a Uralic word speaks in favor of his theory. This is an important observation and contrasts with the situation in Oghur Turkic, because (Proto-)Turkic $*_{-} l A r, *_{-}(A) n, *_{-}, *_{-}$(and other possible and putative plural suffixes mentioned in the literature, see e.g. Pritsak 1957, for Old Turkic specifically see Erdal 2004: 158-160) would not yield $\varnothing$ in Volga Bulgarian and Chuvash, a sound change which could subsequently cause speakers to introduce a new plural morpheme.

This and the peculiarities concerning the accusative in both Volga Bulgarian and ProtoPermic may point to intense contact between these two languages also on fields other than the lexicon. Regarding the plural, it could thus be that the Volga Bulgarians felt the need for a specific plural morpheme when they came into contact with the Proto-Permic speakers. Luutonen 1999: 87 proposed that the Oghur Turkic plural was modeled after the secondary Permic plural. The theory seems more plausible if we assume that Volga Bulgarian did not have

\footnotetext{
${ }^{20}$ Together with cognates in other Uralic languages, these forms are traced back to a Finno-Permic *jäse 'Glied, Gelenk' in Rédei 1988-1991: 95.

${ }^{21}$ Csúcs 2005: 17 dates the dissolution of the Proto-Permic community into the 9th or 10th century.

${ }^{22}$ But note that vowel harmony as such is not a strong argument. As is well-known, the Chuvash possessive marker of the third person, $-\breve{e}$, has resisted vowel harmony for thousands of years, preserving the putative Proto-Turkic situation. Noone would argue that the missing vowel harmony in this suffix means that $-\check{e}$ is a recent, maybe even inner-Chuvash, innovation.
} 
a plural suffix in the first place. Otherwise, it would mean that the genuine Volga Bulgarian plural suffix was replaced by an innovation without any obvious need. Of course, such a scenario cannot be ruled out, but it is quite unlikely, as one may wonder about the incentive.

It should be noted that the new plural marker is also attested earlier in Permic (maybe $1000 \mathrm{CE}$, the dissolution of Proto-Permic) than in Volga Bulgarian (1308, when the inscription containing the plural morpheme was written). This, of course, is a weaker argument than the first one (that the loss of the "general" Uralic and Turkic, respectively, plural is explainable from within Permic, but not from within Volga Bulgarian) because we don't know how long -sem had been in use in Volga Bulgarian already.

The Turkologist Adamović 1983 supposes a Uralic origin of Chuvash -sem, and his hypothesis is followed by Erdal 1993: 87-88 for its Volga Bulgarian cognate. According to Adamović, -sem stems from Finno-Volgaic *-semĕ, which is itself to be derived from a word *semä 'all, totally'. He reconstructs this (Proto-Uralic?) root on account of Mordwin lexemes, Moksha śemb' $\ddot{a} \sim$ śem $\ddot{a}$ 'all' (not used in Erzya) and the Erzya associative plural -mest', a creation from *mese, which represents a metathesized *seme and the plural suffix - $t$ '. - $t$ ' in turn may be cognate to the sibilant affricate in Meadow Mari -̌́amâč. Although a connection with śe 'that' has been suggested (Luutonen 1999: 86), the origin of śemb'ä śemä remains unknown, and neither the Uralisches Etymologisches Wörterbuch (Rédei 1988-1991) nor any other more recent etymological works discuss an etymon *semä or the like. I am skeptical of connecting Erzya -mest' with -sem and -šamâč, and śemb' 'ä is certainly unrelated. Mordvinic itself has preserved the old Uralic plural marker $-t$. But more importantly, for sociolinguistic reasons one would rather expect a borrowing from Volga Bulgarian into proto-Mordvinic than the other way round. ${ }^{23}$ Therefore, this etymology should be discarded.

The hypothesis of a direct Mari origin is likewise very unlikely. There are far more Chuvash loanwords in Mari than vice-versa (see e.g. the list provided in Fedotov 1990: 164322), and the appearance of a Mari plural suffix in Volga Bulgarian epitaphs would be even more surprising. Instead, data from Mari point in the opposite direction of borrowing also in the case of -šamấc. Mari is a language in which the plural marker has traditionally had a very restricted function, being in many cases optional. Possibly, the old Uralic dual and plural categories were given up, and only later, due to contact with other languages, the need to express the plural with a distinct form arose again. This is the reason why the Mari dialects show a variety of plural markers, the majority of them borrowed from surrounding languages. ${ }^{24}$

Plural suffixes are among the easiest suffixes loaned from other languages, and crosslinguistically show a higher degree of innovation than other inflectional endings. ${ }^{25}$ Meadow Mari -vlak, Hill Mari -vlä are thought to stem from a Kipchak form of bölük 'group; division, military

\footnotetext{
${ }^{23}$ For Volga Bulgarian loanwords in Mordvinic see Paasonen 1897; clear incidents of Mordvinic loans in Volga Bulgarian (and Chuvash) have not been found.

${ }^{24}$ Mostly Turkic languages, but even Russian polk 'regiment; group' has been adapted as a marker of multitude in Hill Mari (Luutonen 1999: 89).

${ }^{25}$ To take an example from the Hindukush linguistic area, the borrowing of plural morphemes can be observed among some local languages of Afghanistan and Pakistan (e.g. Pashto, Khowar), which have taken over the animate plural marker $-\bar{a} n$ from Persian. In contrast, neither language makes use of the Persian object marker $-r \bar{a}$, and even the Persian izafet (to form, e.g., genitives) is only used in fossilized phrases.
} 
company' (cf Bashkir bülek 'department, division, sector'), and even the likewise Kipchak -lar has been found in a 18th century manuscript containing Mari words (Luutonen 1999: 91).

Given the other loaned plural suffixes and the fact that it even seems possible that ProtoMari did not know the category of plural at all, or at least did not have specific plural forms, it is probable that $-\check{s}$ amâc too is a borrowing. In this case, the source would have been Chuvash and not Kipchak. The broader use of -vlak / -vlä and variants across the Mari linguistic area in both the eastern and western dialects (Krasnova et al 2017: 67-68) suggests that this suffix is older than -šamâč, but I do not dare to give a precise chronology. In any case, -šamâč cannot be very recent (e.g. last three centuries or less) either, because it is not used in dialects immediately adjacent to current Chuvash-speaking areas.

5. The Chuvash prohibitive marker. Chuvash uses a prohibitive an to form negative commands and wishes. The morpheme is not attested in the Volga Bulgarian corpus, in which only the affirmative imperative appears (Erdal 1993: 65-66). But because of the etymological origin of the prohibitive marker (see below), I argue that it was in fact already present in the Volga Bulgarian language. The particle an comes before the verb it negates, which is unusual for the agglutinating Turkic languages, and does not bear a resemblance to any suffix with the same or a similar meaning in Common Turkic. As examples, the affirmative and prohibitive imperative of the $2 \mathrm{sg}$ and $3 \mathrm{sg}$ in four different Turkic languages are shown.

\begin{tabular}{|l|l|l|l|l|}
\hline Chuvash & Turkish & Uzbek & Altai & Meaning \\
\hline kil & gel & kel & kel & 'come!' \\
\hline an kil & gel-me & kel-ma & kel-be & 'don't come!' \\
\hline
\end{tabular}

Table 4: The 2sg affirmative and prohibitive imperative in Turkic languages

\begin{tabular}{|l|l|l|l|l|l|}
\hline Chuvash & $\begin{array}{l}\text { Volga } \\
\text { Bulgarian }\end{array}$ & Turkish & Uzbek & Altai & Meaning \\
\hline kil-tĕr $^{26}$ & $\begin{array}{l}\text { (bal-tur } \\
\text { 'he/she/it } \\
\text { be!') }\end{array}$ & gel-sin & kel-sin & kel-zin & $\begin{array}{l}\text { 'he/she/it } \\
\text { come!' }\end{array}$ \\
\hline an kil-tĕr & n.a. & gel-me-sin & kel-ma-sin & kel-be-zin & $\begin{array}{l}\text { 'he/she/it come } \\
\text { not!' }\end{array}$ \\
\hline
\end{tabular}

Table 5: The 3sg affirmative and prohibitive imperative in Turkic languages

As regards the prohibitive morpheme, judging from Common Turkic, one could expect Chuvash prohibitive 2sg †kilme and 3sg †kilterme; clearly, this is not the case. But the situation in Chuvash is reminiscent of what we find in Uralic languages. More specifically, an is phonetically close to the $2^{\text {nd }}$ singular/plural negation verb in Udmurt and Komi. Some connection of Chuvash an with the negation verb in the latter two languages has long been suggested, and I argue that the morpheme comes specifically from Proto-Permic. ${ }^{27}$ The use of a negated form of

\footnotetext{
${ }^{26}$ The Chuvash 3 sg imperative in $-t \breve{A r}$ is cognate to the causative marker -DIr in Turkish and other Common Turkic languages. Already Volga Bulgarian uses $-t U r$ for the $3 \mathrm{sg}$ imperative, e.g. in baltur 'he/she/it be' which appears in inscriptions 87 and 93 (Erdal 1993: 65).

${ }^{27}$ For a brief summary of the various theories about the origin of an cf. Fedotov 1996: 43-45.
} 
the auxiliary verb is also found in related languages and is in fact a common Uralic feature. Compare the following examples $(2 \mathrm{sg})$ :

\begin{tabular}{|l|l|l|l|l|}
\hline $\begin{array}{l}\text { Komi (Christian } \\
\text { Pischlöger, } \\
\text { personal } \\
\text { communication) }\end{array}$ & $\begin{array}{l}\text { Udmurt } \\
\text { (Winkler 2001: } \\
\text { 51, 54) }\end{array}$ & $\begin{array}{l}\text { Mari (Riese et al } \\
\text { 2017: 120) }\end{array}$ & Finnish & Meaning \\
\hline lok & likti & tol & tule & 'come!' \\
\hline en lok & en likti & it tol & älä tule & 'don't come!' \\
\hline
\end{tabular}

Table 6: The 2sg affirmative and prohibitive imperative in Uralic languages

In the $3^{\text {rd }}$ person singular/plural, another particle is used in Udmurt. The following table shows the 3 sg imperative:

\begin{tabular}{|l|l|l|l|l|}
\hline $\begin{array}{l}\text { Komi (Christian } \\
\text { Pischlöger, } \\
\text { personal } \\
\text { communication) }\end{array}$ & $\begin{array}{l}\text { Udmurt (Winker } \\
\text { 2001: 51, 54) }\end{array}$ & Mari & Finnish & Meaning \\
\hline med loktas & med likktoz & tolžo & tulkoon & 'he/she/it come!' \\
\hline med oz lok & medaz lǐkti & ănže tol & älköön tulko & $\begin{array}{l}\text { 'he/she/it come } \\
\text { not!' }\end{array}$ \\
\hline
\end{tabular}

Table 7: The 3sg affirmative and prohibitive imperative in Uralic languages

It becomes obvious from these examples that the Komi and Udmurt constructions to negate the imperative are perfectly common in Uralic. In Uralic languages, negation generally happens by means of a negative auxiliary verb (which conjugates for person). From the Komi and Udmurt data we can reconstruct Proto-Permic *en for the $2^{\text {nd }}$ person prohibitive. ${ }^{28}$

Because the $2^{\text {nd }}$ person (singular and plural) is far more often addressed in commands than the $1^{\text {st }}$ and $3^{\text {rd }}$ persons, it was this imperative $* e n$, rather than the Proto-Permic $3^{\text {rd }}$ person (originally optative) *med, which was borrowed into Volga Bulgarian as *än. ${ }^{29}$ Only in the history of Volga Bulgarian, or in any case Chuvash, the particle was reanalyzed as a general prohibitive marker. This explains why in contemporary Chuvash, an can also serve to negate the $3^{\text {rd }}$ person of the imperative mood.

\section{Conclusion}

In this paper, I have tried to point out mutual morphosyntactic influence between Volga Bulgarian and Permic by means of three specific examples. First, the innovated Permic accusative morpheme which could be a calque from Oghur Turkic / Volga Bulgarian. Second, the innovated plural morpheme in both languages which sets them apart from their Turkic and Uralic, respectively, sister languages. The direction of the calque is not entirely clear here. Third, the loan of the Chuvash prohibitive particle from the Proto-Permic negative auxiliary of the $2 \mathrm{sg}$.

\footnotetext{
${ }^{28}$ Csúcs 2005: 71 generally reconstructs $* e$, although the exact distribution and status of Proto-Permic $* e$ and $* \ddot{a}$ are still debated, cf also pp. 67-68. For the imperative $2 \mathrm{sg} / \mathrm{pl}$ of the negation verb cf p. 270.

29 The change Oghur Turkic / Volga Bulgarian $* \ddot{a}>$ Chuvash $a$ is regular. For the development of Proto-Turkic $* \ddot{a}$ in

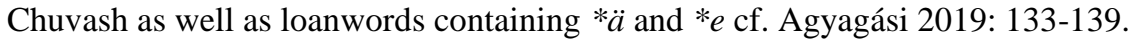


Much in the history of both the Permic languages and Volga Bulgarian including Chuvash is still unclear. Especially problematic is the fragmentary attestation of Volga Bulgarian. Often, we can only assume that Volga Bulgarian must have had a feature which is present in Chuvash but absent from Common Turkic (for instance the Chuvash prohibitive marker). Data from Volga Bulgarian, however, is crucial for the establishment of a more precise history of the language and its contact situations with neighboring languages. Therefore, it goes without saying that any final remarks on the three above-mentioned examples of possible mutual influence would be premature. But I hope to have shown in this paper that Permic and Volga Bulgarian must have influenced each other not only on a lexical level, but also as regards morphology and morphosyntax. I believe that future research on Volga Bulgarian-Permic linguistic contact can find even more shared features between these two languages or language groups.

\section{Literature}

Agyagási, Klára. 2019. Chuvash Historical Phonetics: An areal linguistic study. Wiesbaden: Harrassowitz Verlag.

Adamović, Milan. 1983. Der tschuwaschische Plural -sem, Finnisch-Ugrische Mitteilungen, 7 , 21-27.

Aikio, Ante (Luobbal Sámmol Sámmol Ánte). Forthcoming. Proto-Uralic. In: Bakró-Nagy, Marianne \& Laakso, Johanna \& Skribnik, Elena (eds). The Oxford Guide to the Uralic Languages. Oxford: Oxford University Press. 1-61.

Benzing, Johannes. 1959. Das Tschuwaschische. In: Deny, Jean \& Grønbech, Kaare \& Scheel, Helmuth \& Togan, Zeki Velidi (Hrsg.) Philologiae Turcicae Fundamenta 1, 695-751. Aquis Mattiacis: Steiner.

Benzing, Johannes. 1993. Bolgarisch-tschuwaschische Studien. Wiesbaden: Harrassowitz Verlag.

Budenz, József. 1864. Cseremisz tanulmányok, Nyelvtudományi Közlemények, 3, 397-470.

Csúcs, Sándor. 2005. Die Rekonstruktion der permischen Grundsprache. Budapest: Akadémiai Kiadó.

Erdal, Marcel. 1993. Die Sprache der wolgabulgarischen Inschriften. Wiesbaden: Harrassowitz Verlag.

Erdal, Marcel. 2004. A Grammar of Old Turkic. Leiden: Brill.

Fedotov, M. R. 1990. Čuvašsko-marijskie jazykovye vzaimosvjazi. Saransk: Izdatel'stvo Saratovskogo universiteta.

Fedotov, M. R. 1996. Etimologičeskij Slovar' Čuvašskogo Jazyka. $1^{\text {st }}$ vol. Čeboksary: Čuvašskij Gosudarstvennyj Institut Gumanitarnyx Nauk.

Krasnova, Nadezhda; Riese, Timothy; Yefremova, Tatiana; Bradley, Jeremy 2017. Reading Hill Mari Through Meadow Mari. [Release 1.0] Vienna: University of Vienna. [published online at rhm.mari-language.com] 
Levitskaja, L. S. 1976. Istoričeskaja Morfologija Čuvašskogo Jazyka. Moskva: Izdatel’stvo "Nauka".

Luutonen, Jorma. 1999. The history of Permian, Mari and Chuvash plural suffixes in the light of Indo-Aryan parallels, Journal de la Société Finno-Ougrienne, 88, 73-101.

Lytkin, Vasilij Il'ič. 1952. Drevnepermskij Jazyk. Moskva: Izdatel'stvo Akademii Nauk SSSR.

Paasonen, Heikki. 1897. Die türkischen Lehnwörter im Mordwinischen. Helsingfors: Druckerei der finnischen Litteratur-Gesellschaft.

Pritsak, Omeljan. 1957. Tschuwaschische Pluralsuffixe, Studia Altaica (Festschrift für Nikolaus Poppe zum 60. Geburtstag am 8. August 1957), 137-155.

Ramstedt, Gustaf John. 1952. Einführung in die altaische Sprachwissenschaft. II: Formenlehre. Bearbeitet und Herausgegeben von Pentti Aalto. Helsinki: Suomalais-Ugrilainen Seura.

Rédei, Károly; Róna-Tas, András. 1982. Proto-Permian and Votyak loan-words in Chuvash, Studia Uralo-Altaica, 17, 158-179.

Rédei, Károly; Róna-Tas, András. 1983. Early Bulgarian Loanwords in the Permian Languages, Acta Orientalia Academiae Scientiarum Hungaricae, 37, 1/3, 3-41.

Rédei, Károly (Hrsg). 1988-1991. Uralisches Etymologisches Wörterbuch. Wiesbaden: Harrassowitz Verlag.

Riese, Timothy; Bradley, Jeremy; Yakimova, Emma; Krylova, Galina. 2017. Onaj marij jâlme: A Comprehensive Introduction to the Mari Language. Vienna: University of Vienna. [published online under omj.mari-language.com]

Wichmann, Yrjö. 1923. Zur permischen Grammatik, Finnisch-Ugrische Forschungen, 16, 146163.

Winkler, Eberhard. 2001. Udmurt. München: Lincom. 